\title{
Coupling of Liquid Crystals to Silica Nanoparticles
}

\author{
Vincent Rachet, Khalid Lahlil, Mathieu Bérard, Thierry Gacoin, Jean-Pierre Boilot*
}

Physique le la Matière Condensée, CNRS, Ecole Polytechnique, 911128- Palaiseau (France).

jean-pierre.boilot@polytechnique.fr

\section{SUPPORTING INFORMATION}

\section{Experimental procedures}

\section{Materials}

Hydrosilylation reactions were carried out under a dried $\mathrm{N}_{2}$ atmosphere. THF was dried by distillation over the blue solution of sodium and benzophenone. Chlorosilane $\mathrm{HSiMe}{ }_{2} \mathrm{Cl}$ and platinum catalyst $(\mathrm{Pt} / \mathrm{C})$ were purchased from Aldrich Chemical Co. and used without further purifications. The crystal liquid BL24 was purchased from Merck and the MA-ST suspension of silica nanoparticles from Nissan (30 wt $\%$ in methanol and containing 2 wt $\%$ of water). Elemental analyses were performed by the Central Laboratory of CNRS (Vernaison, France). NMR spectra were obtained with a 300MHz Bruker spectrometer and were measured using $\mathrm{CDCl}_{3}$. The chemical shifts expressed in ppm are reported in $\delta$ relative to tetramethylsilane (TMS) as an internal reference for ${ }^{1} \mathrm{H}$ spectra.

\section{Synthesis of L1 molecules}

L1 molecules were prepared from the following reaction :
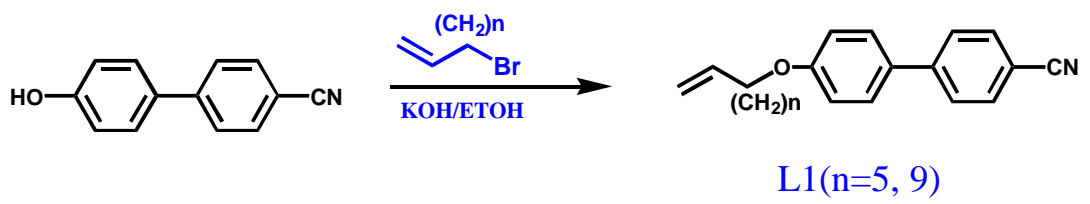

$\mathbf{L 1}(\mathbf{n}=9)$. Into a stirred solution of potassium hydroxide $0.86 \mathrm{~g}(154 \mathrm{mmol})$ in ethanol $(25 \mathrm{ml})$ was added $3 \mathrm{~g}$ (15.4 mmol) of 4-cyano4'-hydroxybiphenyl. A yellow precipitate appears which can be dissolved in refluxed ethanol. To this homogenous solution was added drop by drop the 11-bromo-1hexene and refluxed overnight. The solvent was then evaporated and the residue was extracted with $30 \mathrm{ml}$ of dichloromethane. The insoluble salts of potassium bromide formed were filtered and the solvent was evaporated. The obtained solid was purified by flash chromatography eluting with dichloromethane/cyclohexane (50/50) yielding $65 \%$ of pure product which can be crystallized from ethanol at $-18^{\circ} \mathrm{C}$.

$\operatorname{NMR}\left(\delta_{\mathrm{H}}, \mathrm{CDCl}_{3}\right): 7.6(\mathrm{q}, 4 \mathrm{H}), 7.5(\mathrm{~d}, 2 \mathrm{H}), 7.0(\mathrm{~d}, 3 \mathrm{H}), 5.8(\mathrm{~m}, 1 \mathrm{H}), 5.0(\mathrm{t}, 2 \mathrm{H}), 4.0(\mathrm{t}, 2 \mathrm{H}), 2.0(\mathrm{q}, 2 \mathrm{H}), 1.8(\mathrm{~m}, 2 \mathrm{H}), 1.3(\mathrm{~m}$, $12 \mathrm{H})$. NMR $\left(\delta_{\mathrm{c}}, \mathrm{CDCl}_{3}\right)$ : Aliphatic carbon : $(26.12 ; 28.99 ; 29.22 ; 29.30 ; 29.48 ; 29.53 ; 29.62 ; 33.91) \mathrm{CH} 2-\mathrm{O}(68.16)$; Vinylic 
(114.26; 139.21); Aromatic (109.99; 115.08; 127.03; 128.33; 131.13; 132.57; 145.21; 159.84) CN(119.74). Anal. Calcd for $\mathrm{C}_{24} \mathrm{H}_{24} \mathrm{NO}: \mathrm{C}, 82.95 ; \mathrm{H}, 8.41 ; \mathrm{N}, 4.03$; O,4.60 Found: $\mathrm{C}, 82.56$; H,8.56; N,3.91.

$\mathbf{L 1}(\mathbf{n}=\mathbf{4})$. The same procedure as $\mathbf{L 1}(\mathbf{n}=\mathbf{9})$ was used. The obtained solid is purified by flash chromatography eluting with cyclohexane/ethyle acetate (70/30), yielding $60 \%$ of pure product which can be crystallized from ethanol at $-18^{\circ} \mathrm{C}$.

$\operatorname{NMR}\left(\delta_{\mathrm{H}}, \mathrm{CDCl}_{3}\right): 7.6(\mathrm{~m}, 4 \mathrm{H}), 747(\mathrm{~m}, 2 \mathrm{H}), 6.93(\mathrm{~m}, 2 \mathrm{H}), 5.78(\mathrm{~m}, 1 \mathrm{H}), 4.95(\mathrm{~m}, 2 \mathrm{H}), 3.96(\mathrm{t}, 2 \mathrm{H}), 2.07(\mathrm{q}, 2 \mathrm{H}), 1.78(\mathrm{~m}$, $2 \mathrm{H}), 1.53(\mathrm{~m}, 2 \mathrm{H})$. NMR $\left(\delta_{\mathrm{c}}, \mathrm{CDCl}_{3}\right)$ : Aliphatic carbon : $(25.34 ; 28.70 ; 33.48) \mathrm{CH} 2-\mathrm{O}(67.94)$; Vinylic $(114.89 ; 138.50)$; Aromatic (110.01; 115.08; 127.09; 128.36; 131.27; 132.60; 145.26; 159.73 ) $\mathrm{CN}(119.19)$. Anal. Calcd for $\mathrm{C}_{19} \mathrm{H}_{19} \mathrm{NO}$ : C,82.28; H,6.90; N,5.05; O,5.77 Found: C,82.06; H,7.03; N,4.91.

\section{Synthesis of L2 molecules}
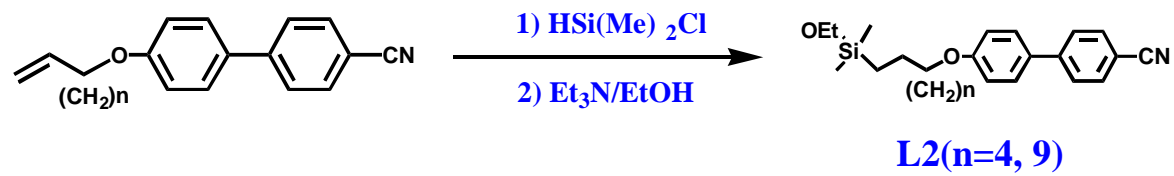

A mixture of 1 equiv of $\mathbf{L 1}(n=4$ or $n=9), 3$ equiv of the dimethylchlosilane and $5 \%$ of dried platinum catalyst (Pt on activated carbon, $10 \%$ Pt content) in 30ml of THF was stirred overnight at room temperature. When the reaction was complete according to ${ }^{1} \mathrm{H}$ NMR, the solvent and the excess of chlorosilane were removed under reduced pressure, leaving a colourless solid, which was very sensitive to moisture. The obtained solid was dissolved in dry THF and 9 equivalents of triethylamine were carefully added. The solution was then maintained between 0 and $5^{\circ} \mathrm{C}$, and finally 9 equivalents of ethanol were added drop by drop by a syringe at a sufficient low rate to avoid an increase of the temperature. The ammonium salts were precipitated in pentane and filtered off. The resulting compounds were purified by flash chromatography on silica gel using dichloromethane as eluant to yield the following compounds :

$\mathbf{L} 2$ (n = 9). $3.5 \mathrm{~g}(10 \mathrm{mmol})$ of $\mathbf{L 1}, 3.3 \mathrm{ml}$ (30 mmol, 3 equiv.) of dimethylchlosilane, $175 \mathrm{mg}$ of Pt/C, $12.5 \mathrm{ml}(90 \mathrm{mmol})$ of triethylamine and $10.5 \mathrm{ml}$ of ethanol $(180 \mathrm{mmol})$ were used. The product was obtained as a clear colourless solid (90\% yield).

$\operatorname{NMR}\left(\delta_{\mathrm{H}}, \mathrm{CDCl}_{3}\right): 7.6(\mathrm{q}, 4 \mathrm{H}), 7.5(\mathrm{~d}, 2 \mathrm{H}), 7.0(\mathrm{~d}, 3 \mathrm{H}), 4.0(\mathrm{t}, 2 \mathrm{H}), 3.6(\mathrm{~m}, 2 \mathrm{H}), 1.8(\mathrm{~m}, 2 \mathrm{H}), 1.3(\mathrm{~m}, 18 \mathrm{H}), 1.2(\mathrm{t}, 3 \mathrm{H}),, 0.09(\mathrm{~s}$, $2 \mathrm{H}) .\left(\delta_{\mathrm{c}}, \mathrm{CDCl}_{3}\right): \mathrm{Si}(\mathrm{CH} 3) 2:-2.01 ; \mathrm{Si}-\mathrm{CH} 2$ (16.40) Si-OCH2CH3 (17.93); Aliphatic carbon : $(17.93 ; 18.46 ; 18.64 ; 23.25 ;$ $26.09 ; 26.16 ; 29.27 ; 29.41 ; 29.46 ; 29.63 ; 29.68 ; 33.52) \mathrm{CH} 2-\mathrm{O}(68.16) ; \mathrm{SiOCH} 2(58.22)$ Aromatic (109.98; 115.08; 127.03; $128.31 ; 131.15,132.55 ; 145.24 ; 159.83) \mathrm{CN}(119.12)$. Anal. Calcd for $\mathrm{C}_{29} \mathrm{H}_{43} \mathrm{NO}_{2} \mathrm{Si}: \mathrm{C}, 74.45 ; \mathrm{H}, 9.15 ; \mathrm{N}, 3.10 ; \mathrm{O}, 7.08$; Si,6.22 Found: C,74.46; H,9.24; N,3.03; Si,6.25.

L2 $(\mathbf{n}=4) .1 .25 \mathrm{~g}(4.72 \mathrm{mmol})$ of $\mathbf{L 1}, 1.6 \mathrm{ml}(14.4 \mathrm{mmol}, 3$ equiv.) of dimethylchlosilane, $80 \mathrm{mg}$ of $\mathrm{Pt} / \mathrm{C}, 5.7 \mathrm{ml}(41 \mathrm{mmol})$ of triethylamine and $4.8 \mathrm{ml}$ of ethanol $(83 \mathrm{mmol})$ were used. The product was obtained as a clear colourless solid (90\% yield).

$\operatorname{NMR}\left(\delta_{\mathrm{H}}, \mathrm{CDCl}_{3}\right): 7.68(\mathrm{~m}, 4 \mathrm{H}), 7.52(\mathrm{~m}, 2 \mathrm{H}), 7.0(\mathrm{~m}, 2 \mathrm{H}), 4.01(\mathrm{t}, 2 \mathrm{H}), 3.67(\mathrm{q}, 2 \mathrm{H}), 1.81(\mathrm{~m}, 2 \mathrm{H}), 1.34-1.55(\mathrm{~m}, 6 \mathrm{H}), 1.19(\mathrm{t}$, $3 \mathrm{H}),, 0.61\left(\mathrm{t}, 2 \mathrm{H}, 0.10(\mathrm{~s}, 6 \mathrm{H}) .\left(\delta_{\mathrm{c}}, \mathrm{CDCl}_{3}\right): \mathrm{Si}(\underline{\mathrm{CH}} 3) 2\right.$ : -2.01; Si-CH2 (16.36) Si-OCH2CH3 (18.65); Aliphatic carbon : (18.64; 23.19; 25.77; 29.17; 33.14; 33.19;) $\mathrm{CH} 2-\mathrm{O}$ (68.16); $\mathrm{SiOCH} 2$ (58.25) Aromatic (109.98; 115.08; 127.07; 128.34, $131.20 ; 132.58 ; 145.27 ; 159.80) \mathrm{CN}(119.17)$. Anal. Calcd for $\mathrm{C}_{25} \mathrm{H}_{35} \mathrm{NO}_{2} \mathrm{Si}: \mathrm{C}, 72.39 ; \mathrm{H}, 8.19 ; \mathrm{N}, 3.67 ; \mathrm{O}, 8.39 ; \mathrm{Si}, 7.36$ Found: C,70.06; H,8.29; N,3.48; Si,6.67.

\section{Grafting of L2 molecules on silica nanoparticles}




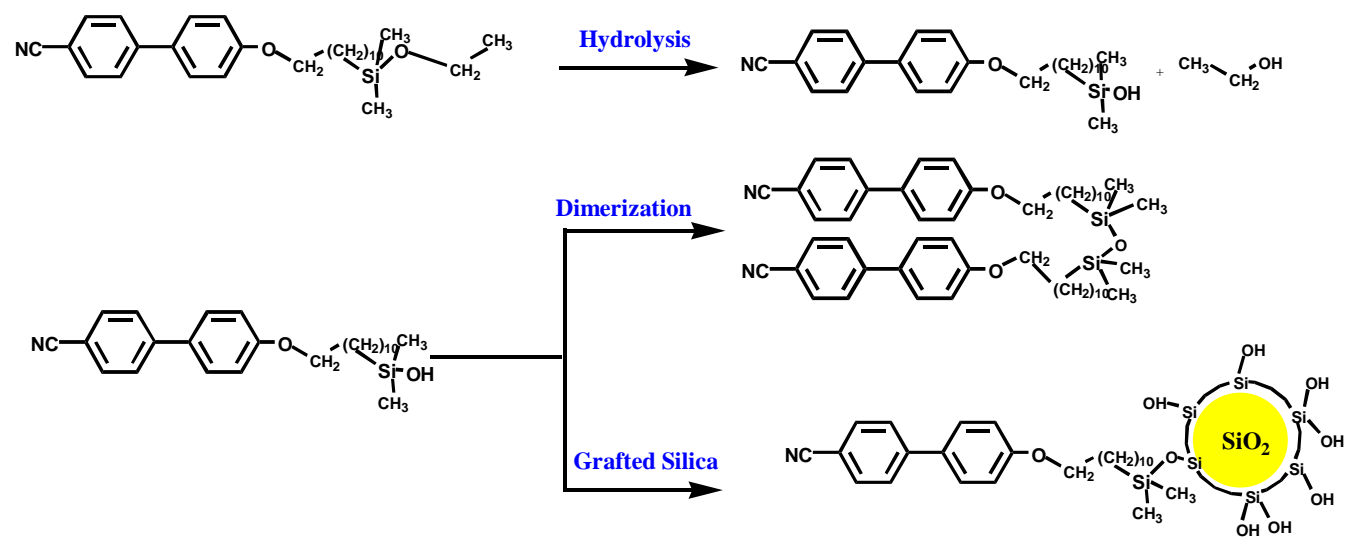

$\mathrm{L} 2 ~^{\mathrm{SiO}_{2}}$

$500 \mathrm{mg}$ of $\mathbf{L 2}(\mathrm{n}=4)(1.3 \mathrm{mmol})$ and $1.95 \mathrm{~g}$ of silica nanoparticles were mixed together in DMF. The resulting solution was stirred and refluxed for about 100 hours, yielding a clear solution. Purification of the grafted silica nanoparticles was done by precipitating all the species in solution with $13 \mathrm{ml}$ of methanol. Particles were then isolated by centrifugation at $8000 \mathrm{rpm}$ for $10 \mathrm{~min}$. The supernatant was discarded and the remaining precipitate was then triturated six times with $10 \mathrm{ml}$ of toluene and separated by centrifugation to eliminate the remaining molecular species. Purified grafted nanoparticles were dispersed in DMF and filtered off at $450 \mathrm{~nm}$. Pure grafted nanoparticles were characterized by the absence of the signals in ${ }^{1} \mathrm{H}$ liquid NMR corresponding to molecular species and no spot in chromatography (TLC), when eluting with 80/20 (cyclohexane/ethyl acetate). The hydrolyzed and the dimer species have respectively a retention factor $R_{f}=0.6$ and $R_{f}=0.25$.

\section{Characterizations of silica nanoparticles}

Particles sizes and distributions were measured by Dynamic Light Scattering (DLS) at $488 \mathrm{~nm}$ using a PCS (photon correlation spectroscopy) light scattering equipment supplied by Malvern. Transmission electronic Microscopy (TEM) was performed on a Philips CM30 TEM/STEM operating at $300 \mathrm{kV}$. Figure S1 shows shape and size of nanoparticles in MA-ST silica suspensions. The hydrodynamic diameter, deduced from dynamic light scattering measurements $(18 \mathrm{~nm})$ is similar to the average diameter observed on TEM photographs (14 nm, counting on about 50 particles), showing that starting colloids are formed of isolated and well dispersed silica nanoparticles. Note that no significant change of average size of particles was detected in suspensions of LC grafted particles showing that the grafting process did not provide a partial aggregation of the silica particles.

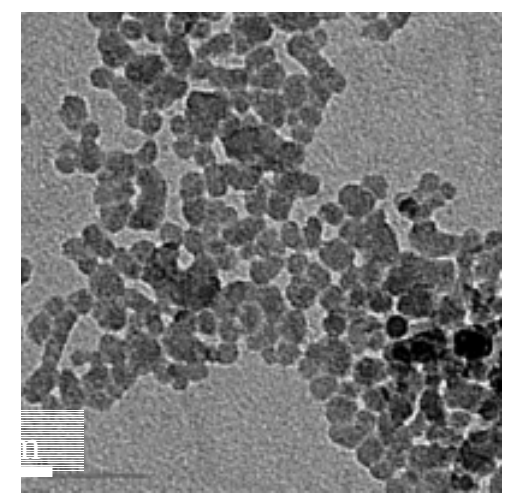

Figure S1 : TEM photograph of silica MA-ST colloids. 


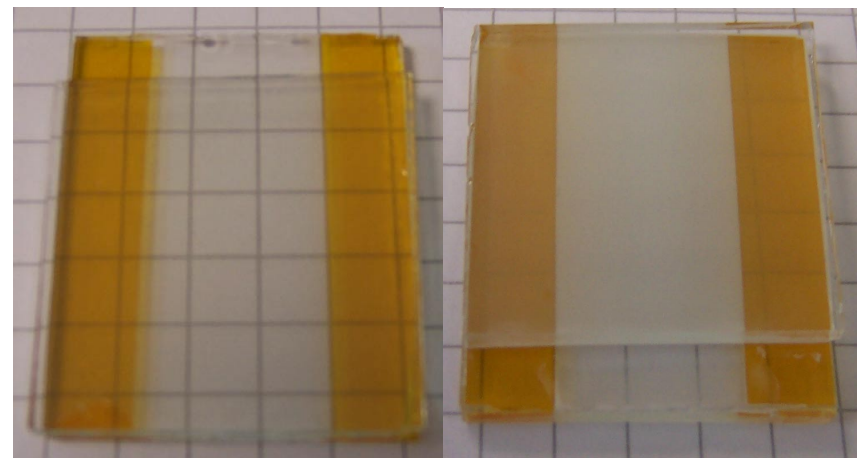

Figure S2 : Macroscopic equivalent to Figure 2 with photographs of cells showing the visible appearance of both PDLC from standard mixture without nanoparticles (left) and PDLC from a mixture containing LC grafted silica nanoparticles as nucleation centers (right). The pattern of squares has a surface of $5 * 5 \mathrm{~mm}^{2}$. 